\title{
EL DESCANSO DEL GUERRERO: \\ LA TRANSFORMACIÓN DE LA MASCULINIDAD \\ EXCOMBATIENTE FRANQUISTA (1939-1965)
}

\section{The recreation of the warrior: The transformation of the Francoist veterans' masculinity (1939-1965)}

\author{
ÁNGEL ALCALDE \\ Ludwig-Maximilians-Universität München \\ angel.alcalde@lmu.de
}

Cómo citar/Citation

Alcalde, Á. (2017).

El descanso del guerrero: la transformación de la masculinidad excombatiente franquista (1939-1965)

Historia y Política, 37, 177-208.

doi: https://doi.org/10.18042/hp.37.07

(Recepción: 30/05/2016. Evaluación: 04/07/2016. Aceptación: 07/12/2016. Publicación: 26/05/2017)

\section{Resumen}

La implantación del franquismo en España implicó la consolidación de una serie de roles y relaciones de género de carácter ultraconservador, católico o fascista, así como ideales de masculinidad, que han sido poco investigados por los historiadores hasta ahora. Este artículo examina la evolución histórica de un arquetipo de masculinidad que consideramos hegemónico durante gran parte de la dictadura: el modelo del excombatiente franquista. A través del análisis de fuentes periodísticas, literatura y cine, y observando la dimensión íntima y familiar de la generación de hombres que ganaron la Guerra Civil, el artículo explica las implicaciones y transformaciones de aquel ideal varonil a través de la idea fuerza del «descanso del guerrero». La mitificada concepción de hombre como veterano de guerra, que fusionándose con modelos masculinos diferentes logró mantener su hegemonía en la sociedad española, 
fue una clave para sostener el orden sociofamiliar y de relaciones de género hasta mediados de los años sesenta.

\title{
Palabras clave
}

Excombatientes; franquismo; masculinidad; familia; relaciones de género.

\begin{abstract}
The establishment of the Franco regime entailed the consolidation of a set of ultra-conservative, Catholic, and fascist gender roles, as well as masculinity ideals. However, Francoist masculinity has been largely neglected by historians. This article examines the historical evolution of Francoist war veterans as a manly archetype. The article argues that this ideal of masculinity was hegemonic during most part of the dictatorship. By analysing journalistic, literary and filmic sources, and by observing the intimate and familiar dimension of the lives of men who fought and won the Spanish Civil War, the article explains the implications and transformations of such manly ideal, which drew on the driving notion of the "recreation of the warrior". A mythical conception of the man as a war-experienced individual preserved its hegemony by fusing with other masculinity models, thus becoming a key factor to sustain social and familiar order and gender relations in Spanish society until the mid-1960s.
\end{abstract}

\section{Keywords}

Veterans; Francoism; masculinity; family; gender relations. 
I. INTRODUCCIÓN. II. LOS AÑOS CUARENTA. III. LOS AÑOS CINCUENTA. IV. LOS AÑOS SESENTA. V. CONCLUSIÓN. Biblografía.

\section{INTRODUCCIÓN}

La historia de las masculinidades en la España del franquismo es un campo todavía muy poco cultivado por los investigadores contemporaneístas, aunque en los últimos tiempos se hayan publicado importantes aproximaciones al tema ${ }^{2}$, el cual atrae cada vez más interés. La relevancia de nociones ideales de masculinidad y virilidad en la sociedad y la política franquista es difícil de negar, sobre todo tratándose el régimen de una dictadura que mantuvo fuertes componentes fascistas y tradicionalista católicos durante toda su trayectoria. Ante todo, y dada la importancia del estudio de la masculinidad en relación con las experiencias de guerra ${ }^{3}$, la íntima relación del franquismo con lo bélico, en general, y con la Guerra Civil, en particular, obliga a considerar atentamente los modelos ideales de masculinidad franquista que, al igual que el régimen, surgieron del conflicto armado de 1936-1939, pero experimentaron importantes transformaciones posteriores que están en buena medida todavía por descubrir.

Este artículo explora la evolución y metamorfosis a medio y largo plazo de lo que probablemente fue uno de los ideales de masculinidad hegemónicos en la dictadura ${ }^{4}$ : el modelo del excombatiente franquista. Este ideal se

1 Este artículo ha sido posible gracias al apoyo del programa «Salvador de Madariaga» del Ministerio de Educación, Cultura y Deporte. El autor ha formado parte del proyecto HAR2012-32539, «Discursos e identidades de género en las culturas políticas de la derecha española, 1875-1975», financiado por el Ministerio de Economía y Competitividad.

2 Nash (2014); Winchester (2015).

3 Crouthamel (2014); Meyer (2009); Hagemann y Schüler-Springorum (2002); Hämmerlev et al. (2014), y Corbin et al. (2011): passim.

4 Nuestra aplicación del concepto de «masculinidad hegemónica» no solo implica hegemonía sobre el género femenino, sino también una «hegemonía interna», es decir, sobre otras masculinidades o grupos de hombres. Véanse Donaldson (1993); Demetriou (2001), y Connell y Messerschmidt (2005). La masculinidad hegemónica puede 
caracterizó por implicar la exaltación de la experiencia de guerra en el bando victorioso como elemento fundamental de definición, afirmación y demostración de la virilidad del varón español. Tal énfasis en el servicio de armas realizado exitosamente, como rasgo definitivo y definitorio de la masculinidad modélica, no solo permitió al régimen reforzar la conexión identitaria de muchos hombres con el mito fundacional del franquismo - la Guerra Civil—, sino que además ofrecía un marco identitario de género en el que podían reunirse, como bajo un paraguas, distintos ideales de masculinidad promovidos por los diversos sectores de la coalición política del bando franquista, desde el falangismo hasta el tradicionalismo. Además, este ideal viril permitía a muchos individuos reconocerse en el mito masculino de Franco como héroe militar $^{5}$. La pluralidad interna de un arquetipo de masculinidad enraizado en la vivencia del combate y el servicio de armas, directamente conectado con la imagen construida del propio jefe de Estado, permitió que este ideal pudiese conservar su hegemonía durante largo tiempo. Mary Vincent ha argumentado que, tras la victoria de 1939, ideales paternalistas enraizados en el carlismo desplazaron en todo el país a las imágenes varoniles agresivas de tipo fascista que había promovido el falangismo durante la guerra ${ }^{6}$. Esta dicotomía de modelos, no obstante, pienso que no capta completamente la complejidad y los procesos de cambio experimentados por el ideal del excombatiente de masculinidad en la larga posguerra y en las décadas de los años cincuenta y sesenta. Aquí partiré de la idea de que al acabar el conflicto bélico la amalgamación de ideales fascistas y tradicionalistas en un ideal de masculinidad excombatiente específicamente franquista no significó el abandono de elementos de raíz fascista apoyados en la experiencia bélica. Es más, durante los años cincuenta y sesenta, veremos cómo dichos componentes más violentos del modelo de virilidad permanecieron, aunque el ideal se transformó sustancialmente abrazando terceros ingredientes nuevos y muy distintos, y sobreviviendo crisis que acompañaron el desarrollo de la sociedad española en las décadas centrales del novecientos.

La clave de bóveda de ese cambiante sistema de valores, símbolos, prácticas y discursos que compusieron el ideal hegemónico de masculinidad excombatiente franquista fue, hipotéticamente, la idea fuerza del "descanso del guerrero». Este tropo con origen en la filosofía de Nietzsche, sin llegar claramente a convertirse en un arma discursivo ideológica de los movimientos

cambiar y adoptar nuevas prácticas para permitir a unos hombres conservar poder sobre otros: Ducanson (2015).

5 Sobre el mito de Franco véanse Zenobi (2011); Sevillano (2010), y Cazorla (2015).

6 Vincent (2006); cf. Aresti (2012 y 2014). 
reaccionarios de comienzos del siglo Xx, había contribuido a dar forma al antifeminismo de principios de la centuria en Europa ${ }^{7}$. Aquel argumento que Nietzsche puso en boca de su Zaratustra se fundamentaba en las supuestas diferencias entre sexos: el hombre — que ama el peligro y el juego- debe ser educado para la guerra; la mujer debe serlo para el descanso del guerrero (Erholung des Kriegers) ${ }^{8}$. En cierto sentido, esta idealización de esferas separadas con un giro dionisíaco y vitalista no desentonaba completamente con las concepciones predominantes de la mujer como «ángel del hogar» de la sociedad burguesa decimonónica, ni con el ideal de «hogar cristiano» predicado por la Iglesia católica y el tradicionalismo, como tampoco desarmonizaba con el ideal mediterráneo con profundas raíces históricas de varón "preñador, protector y proveedor»" Además, a partir de la experiencia de la Primera Guerra Mundial y de la Guerra Civil en España, esa visión nietzscheana pudo ser implementada en la realidad a través de la política antifeminista de los fascismos ${ }^{10}$, los cuales se fundamentaban precisamente en una valoración positiva de la violencia y de la guerra, además de en la glorificación de la figura del soldado y del excombatiente ${ }^{11}$. De acuerdo con esto, como veremos, la noción del «descanso del guerrero» sintetiza no solamente la idealización franquista de lo femenino, sino que también colma de sentido la transformación histórica, con su fusión de elementos diversos, de un ideal hegemónico de masculinidad en el régimen de Franco: el del excombatiente. Este ideal permitió —en mi opinión — imponer un modelo jerárquico de patriarcado, unas pautas para las relaciones entre hombres y mujeres, y un determinado orden sociofamiliar en la sociedad española del siglo XX.

Para demostrar esto, este artículo se inspira en una serie de perspectivas historiográficas que se yuxtaponen a la historia de género, ya que nos interesa no únicamente comprender la formación de ideales de masculinidad y feminidad, sino su repercusión en la esfera íntima de las familias y la sociedad de la época. La historia de la familia, junto a la historia del cuerpo, del consumo y de la moda, así como la historia de las emociones ofrecen puntos de vista de

7 Véase Joran (1905): 439-441; Ortega López (2008). Sin embargo, el concepto de «descanso del guerrero» no ha sido, hasta donde sabemos, sistemáticamente estudiado o utilizado como herramienta analítica por los historiadores.

8 Nietzsche (1901): 96. Erholung ha sido traducido a veces como «solaz», porque la palabra alemana posee connotaciones no solo de convalecencia y recuperación, sino también de diversión o recreo.

9 Gilmore (1994): 217. Los mitos en torno al retorno del guerrero también proceden de la antigüedad grecorromana; baste recordar la Odisea de Ulises.

10 Molinero (1998).

11 Mosse (2000 y 2016). 
enorme utilidad para comprender la transformación de ideales masculinos forjados en experiencias bélicas, como han demostrado algunas recientes contribuciones historiográficas en el amplio marco de los estudios culturales sobre la guerra ${ }^{12}$. Aquí, ante la escasez de fuentes epistolares y otros «egodocumentos» para el estudio del franquismo, recurriré sobre todo a la literatura, el cine y la prensa para el análisis.

\section{LOS AÑOS CUARENTA}

Estudios recientes han sugerido que la vivencia de la Guerra Civil española marcó profundamente las identidades de aquellos hombres que combatieron en ella, y que incluso aquella experiencia pudo llegar a configurar no solo modelos de masculinidad hegemónicos, sino las propias relaciones cotidianas entre hombres y mujeres en el seno de la sociedad posbélica española ${ }^{13}$. Ha de recordarse que la guerra total tuvo en España y en otros países europeos el efecto de consolidar o restaurar ideas sumamente conservadoras en materia de género ${ }^{14}$. Y de hecho, muchos de los roles asumidos por mujeres en la movilización bélica, desde convertirse en madrinas de guerra hasta ejercer la prostitución en burdeles para militares, contribuyeron a la percepción de que el «aforismo desdeñoso» de Nietzsche se hacía tierna realidad: «Manos suaves de enfermera cuando pueden restañar heridas, rellenan y muellen un cojín blando para el breve sueño de los desvelados en los duros hielos de Rusia y las ásperas arenas africanas» — describía la crónica de un corresponsal de $A B C$ en Roma a finales de $1941{ }^{15}$.

El ideal de masculinidad excombatiente franquista en la inmediata posguerra no podía, sin embargo, cancelar las durísimas realidades de la vida de los hombres comunes que habían sobrevivido al conflicto, aun habiendo

12 McVeigh y Cooper (2013). Desde la historia del cuerpo, en estrecha relación con la de género, véase el clásico Bourke (1996), que ha sido la inspiración de numerosos trabajos posteriores sobre la mutilación bélica del cuerpo masculino. Véase también Lüdtke (2011). Para la perspectiva sobre las emociones, Roper (2007) y también Bourke (2008). Sobre el mundo familiar e íntimo de los veteranos de guerra véase Fouchard (2013) y Cabanes y Piketty (2009).

13 Alcalde (2013 y 2014).

14 Véase Thébaud (1993) y Cenarro (2006).

15 ABC (Madrid), 19 de diciembre de 1941. Véanse también Manuel Pombo Angulo: «El descanso de las «boîtes»", Fotos. Semanario Gráfico (Madrid), 15 de noviembre de 1942; reportaje «La alegría de la pascua, alivio de los heridos», Fotos, 19 de diciembre de 1942. 
luchado en el ejército victorioso. El largo proceso de desmovilización y reincorporación al mundo civil de cerca de un millón de exsoldados de Franco — jóvenes de entre 18 y 34 años a la altura de 1939 — estuvo marcado por una abrupta disparidad de experiencias ${ }^{16}, \mathrm{y}$ tampoco parece que hubiera ninguna pauta predominante de reintegración emocional y familiar. En cualquier caso, es indiscutible que haber luchado y ganado con el ejército de Franco significaba para muchos haber demostrado su hombría; junto a los voluntarios para la División Azul, jóvenes exalféreces provisionales y exoficiales fueron a menudo la representación estereotípica de ese ideal de masculinidad combatiente de sabor fascista, que se transformaba en el del guerrero que tras dar su sangre regresaba, en la nueva España de Franco, al regazo de «la madre, y el hogar y los besos ${ }^{17}$. Ideas de descanso y reposo se combinaron en el discurso franquista de la primera posguerra con los insistentes llamamientos totalitarios a trabajar, obedecer y callar ${ }^{18}$. Esta era la típica consigna dada por FETJONS a sus excombatientes ${ }^{19}$, mientras que a las afiliadas a la Sección Femenina se les advertía de que el hombre necesitaba la «sana alegría» de la mujer: el hombre, «un poco cansado de la lucha diaria, encuentra en ella un refugio donde todo es transparente y amable $»^{20}$.

A pesar de las difíciles condiciones económicas y sociales, el clima bélico del continente europeo en la primera mitad de los años cuarenta, que contribuyó a mantener las actitudes guerreras también en España, permitió que el arquetipo de masculinidad excombatiente franquista tomase forma y deviniese hegemónico. El ideal varonil fascista que exaltaba la juventud y la violencia todavía animaba a jóvenes que tras haber ganado experiencia en el ejército de Franco o en la División Azul hacían valer sus méritos, sus condecoraciones y ventajas legales (como la famosa Ley de 25 de agosto de 1939) para hacer una carrera civil, continuar estudios en las universidades, obtener un puesto funcionarial, o ejercer prestigiosas profesiones burguesas. En aquellos primeros años tras la Guerra Civil, el éxito personal de los hombres jóvenes — su realización como tales-, tanto en lo profesional como en lo familiar, estuvo estrechamente conectado a su privilegiada condición de excombatiente franquista. Mientras, el enemigo, el vencido, era feminizado y su hombría puesta en entredicho, como

\footnotetext{
Alcalde (2015) y Leira (2013).

Haupold Gay (1941): 83-84.

18 Entre los muchos ejemplos véase J. M. de A [José María de Azaola]: «Descanso», Lar. Revista para la Familia (San Sebastián), núm. 1, 15 de septiembre de 1943

19 "Excombatientes», Arriba (Madrid), 31 de enero de 1940.

20 Medina. Semanario de la SF (Madrid), núm. 3, 3 de abril de 1941. Véase también, por ejemplo, Y. Revista de la Mujer Nacional-Sindicalista, núm.15 (abril de 1939).
} 
ocurría por ejemplo en el cine de Cruzada, el cual a la vez exaltaba la figura del soldado rebelde $e^{21}$. La restauración de la tradicionalista familia católica en el país no solo se apoyó en políticas concretas inspiradas en el fascismo ${ }^{22}$, sino en individuos que habían encarnado el ideal masculino combatiente durante la Cruzada. Aunque las bajas tasas de nupcialidad y natalidad de los años de la Guerra Civil no aumentaron sustancialmente hasta 1946, fueron comunes en ese primer lustro posbélico las bodas entre novias de blanco y novios de uniforme militar, a veces de gala, con guantes blancos y sable, pero sobre todo con medallas en el pecho, como la Cruz de Hierro alemana, o la española Medalla de la Campaña $^{23}$. Según sugieren las escasas estadísticas disponibles ${ }^{24}$, la generación de hombres que hizo la guerra tuvo que retrasar ligeramente su edad de matrimonio, pero ese excepcionalmente amplio sector poblacional de solteros que existía en 1940 se casó en los siguientes diez años más rápidamente y en mayor medida que la generación precedente. Tener hijos, no obstante, fue una experiencia que habitualmente sufrió un ulterior retraso para la generación de excombatientes franquistas: estos, aun estando en ventaja frente a otros grupos para encontrar esposa, muy a menudo fueron padres tardíos, algo que probablemente contribuiría a ahondar la crisis de identidad masculina simultánea a la brecha generacional que, como veremos, se abrió entre mediados de los años cincuenta y mediados de los sesenta entre veteranos franquistas y sus descendientes ${ }^{25}$.

Con todo, el matrimonio y la paternidad fueron los acontecimientos clave para formar y transformar las identidades de género de aquellos hombres en la primera década posbélica: si un exitoso matrimonio claramente podía concebirse como la merecida recompensa y descanso tras combatir una guerra, los hijos eran un ulterior trofeo que confirmaba la virilidad demostrada en los campos de batalla y en la esfera sentimental, aunque implicasen un cambio importante en actitudes y autopercepciones (véase la imagen 1$)^{26}$. Estas reali-

\footnotetext{
Rincón (2014): 339.

22 Véase Confederación Católico Nacional de Padres de Familia (1940): 23-28.

23 Fotografías de bodas en Lar. Revista para la Familia, núm. 1, 15 de septiembre de 1943; Y, núm. 82 (noviembre de 1944); núm. 83-84 (diciembre de 1944-enero de 1945); núm. 90 (julio de 1945); representación ideal de estas bodas en $Y$, núm. 14 (marzo de 1939).

24 Cachinero Sánchez (1982).

25 Sobre las relaciones entre edad avanzada, paternidad y masculinidad, véase Shirani (2013).

26 José A. G., nacido en 1916 y exsargento provisional del ejército de Franco, que se había acogido a ventajas ofrecidas a excombatientes para integrarse en 1940 en el cuerpo de la Guardia Civil, y casado en 1943, alza ante la cámara a su hija
} 
Imagen 1. José A. G. y su hija primogénita Blanca, 1944

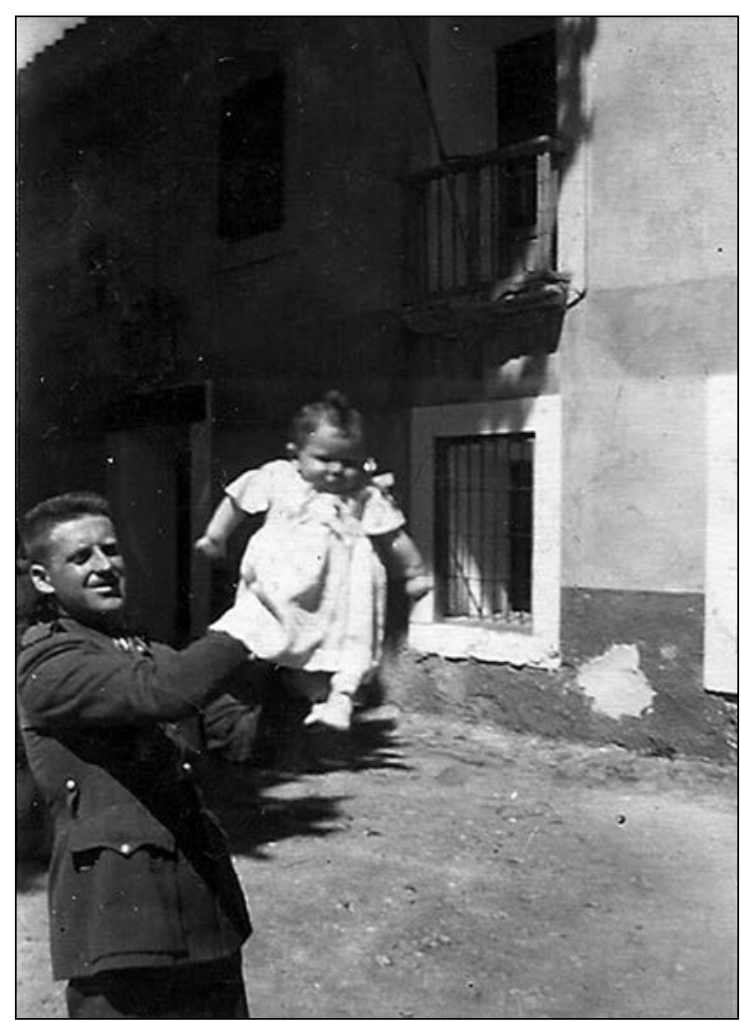

Fuente: archivo del autor.

dades de la vida cotidiana posbélica, si bien se pudieran integrar fácilmente en los ideales masculinos construidos por el franquismo, no encontraron un claro acomodo en el agresivo discurso propagandístico falangista, sobre todo en el contexto coetáneo de declive y derrota del fascismo en Europa. En la segunda mitad de los años cuarenta, el ideal de masculinidad excombatiente franquista prácticamente desapareció del espacio público.

primogénita Blanca (1944). En enero de 1945, José A. G., alegando «necesidad de atender a intereses propios de casa» solicitó y le fue concedida la baja en el cuerpo. Este tipo de trayectorias individuales fueron comunes en la posguerra y ejemplifican cómo acontecimientos familiares y emocionales pudieron influenciar las autopercepciones de la propia masculinidad, pautas de conducta y toma de decisiones con repercusiones sociopolíticas. 
Ciertamente, más que el modelo varonil basado en el horizonte del «descanso del guerrero» que había predominado en la primera posguerra, el ideal de padre trabajador, bueno, católico y piadoso armonizó más con el subsiguiente contexto histórico, y con las realidades cotidianas de una generación de hombres habitualmente angustiados por las incertidumbres económicas y por el deber de sacar adelante a los hijos apenas nacidos ${ }^{27}$. A veces, causaba rubor a esos hombres "conocer el precio del aceite, de las lentejas, del pan, de las patatas", porque esa "cultura de ama de casa», que se veían obligados a portar con ellos a las conversaciones entre hombres en «los casinos, los cafés» y espectáculos, era impropia de su «masculina condición $»^{28}$. Con todo, elementos de esa anterior masculinidad "guerrera» nunca desaparecieron sin más.

Los guerreros no tenían tanto tiempo para su propio descanso en el hogar medio español de mediados y finales de los años cuarenta, aunque con los ardores ideológicos y militares en fase de reflujo, los de edades comprendidas entre los veinticinco y la cuarentena podían encontrar algún esparcimiento y descargo para sus energías varoniles en las opciones de ocio políticamente controladas que permitía la España de Franco. Estas fueron un factor histórico importante para remodelar las masculinidades franquistas tras la crisis política causada por la derrota de los fascismos. Es significativo, por ejemplo, que el conocido periódico deportivo Marca, fundado en 1938 por un hermano del líder falangista Raimundo Fernández-Cuesta, pasase de ser semanario a diario en noviembre de 1942 (aproximadamente a la vez que en Rusia el ejército soviético comenzaba su barredora contraofensiva en Stalingrado). Esta prensa también estuvo sometida a la censura y las directrices del régimen. Así, en el proceso de desfascistización de la dictadura, el mundo del fútbol, en el que se localizaban narrativas como aquella de la «furia española» (a veces casi una alegoría de la situación política española que concordaba muy bien con el discurso ofrecido a los excombatientes franquistas) ${ }^{29}$, asumió una

27 Es probable que el rol del padre en la sociedad española se hubiese transformado en dirección similar a la de otras sociedades europeas desde 1914, y especialmente desde los años treinta, con un mayor énfasis no solamente en los deberes básicos del padre hacia sus hijos, proporcionando educación y sustento, sino también regalos, propinas y chucherías. Véase King (2015).

28 Vida. Revista para mi familia (Madrid), Núm. 1 (febrero de 1948).

29 Sobre uno de los muchos encuentros futbolísticos de esos años entre España y Portugal, se comentaba: «Nuestros muchachos sacarán la tradicional furia española; improvisarán, obedecerán disciplinadamente las instrucciones y conseguirán que la marca de imbatidos permanezca [...]», Fotos, 10 de marzo de 1945. La cursiva es mía. 
creciente relevancia social para públicos claramente masculinizados ${ }^{30}$. Dado que existía una clara vinculación entre el fútbol y la virilidad a través de ideas de fuerza y agresividad, y teniendo en cuenta que las crónicas deportivas empleaban asiduamente metáforas bélicas ${ }^{31}$, fue fácil dar cauce a la masculinidad excombatiente dando más espacio a los ideales varoniles deportivos. De igual manera, los toros, espectáculo violento que en aquella época tenía todavía un enorme seguimiento popular, también sirvieron como lugar donde unas pautas de masculinidad agresiva podían reconducirse. Franco y diversas autoridades como el general Moscardó (delegado nacional de Deportes) a menudo asistían a las plazas, donde en mayo de 1945 se alzaban brazos en saludo fascista, los toreros brindaban al Caudillo, y se oían gritos de ¡Franco, Franco, Franco! ${ }^{32}$

Es interesante notar cómo en aquel periodo las figuras masculinas representadas positivamente en la prensa sutilmente reciclaban todavía valores enraizados en la experiencia de guerra. Y esto valía también para los nuevos modelos de hombre que vinieron con el masivo desembarco de la cultura estadounidense en Europa desde mediados de los años cuarenta. Del norteamericano Clark Gable la prensa española destacó también que había cumplido los deberes militares durante la guerra; algo que le había mantenido temporalmente alejado de la cinematografía ${ }^{33}$. Este actor se había convertido en todo un icono de virilidad en el que, dados sus cabellos morenos, una generación de españoles podía fácilmente tratar de identificarse, adoptando su «elegancia discreta» e incluso ese característico bigote de «seducción tremenda»" ${ }^{34}$. Un «héroe deportivo» como el propio Santiago Bernabéu, que ejerció un rol crucial en el Real Madrid de la larga posguerra, también había hecho la guerra en el ejército de Franco, nada menos que bajo las órdenes directas de Agustín Muñoz Grandes ${ }^{35}$. En la prensa gráfica española posterior a la Segunda Guerra Mundial podía encontrarse una positiva representación del «hombre culto», del "caballero» con "la calva, las gafas y el pitillo», que conoce el «arte de leer periódicos», junto a exaltaciones del héroe de guerra caído por España: de esa «mocedad española» que «murió con las botas puestas», con ese

30 La tesis de la desfascistización en Gallego (2014). Sobre fútbol, Quiroga (2014).

31 Uría (2014): 183.

32 Marca (Madrid), 21 de mayo de 1945.

33 Marca, 10 de enero de 1945.

$34 A B C, 16$ de diciembre de 1945; Fotos, 20 de julio de 1946.

35 Viuda-Serrano (2013). Sobre la utilización posterior del «héroe deportivo» véase Simón Sanjurjo (2012). 
«atributo de caballero», "primera postura de la virilidad ${ }^{36}$. Aquel fue un proceso de reconversión simbólica muy largo, correspondiente a la larga travesía en el desierto del régimen, pero que implicaría una creciente presencia de elementos nuevos, que en la década de los cincuenta se integraron sustancialmente en un renovado modelo de masculinidad franquista todavía comprensible en el marco del «descanso del guerrero».

\section{LOS AÑOS CINCUENTA}

Desde 1945, y sobre todo en los años cincuenta, España no fue ajena a la fuerte irradiación cultural de los Estados Unidos, que se había convertido en la mayor potencia del globo tras la Segunda Guerra Mundial, y cuyo anticomunismo en el contexto de la Guerra Fría lo convertía en casi el único referente al que mirar en busca de la orientación necesaria para reconfigurar las identidades masculinas de la generación de excombatientes franquistas. Es importante tener en cuenta que en Norteamérica, la considerada greatest generation $^{37}$, los cerca de dieciséis millones de veteranos de guerra que se reincorporaron al mundo civil tras 1945, tuvo una influencia gigantesca sobre su país durante las presidencias de Truman (un excombatiente de la Primera Guerra Mundial) y Eisenhower (héroe militar de la Segunda). Allí, gracias entre otros factores a la famosa GI Bill (una ley de beneficios para veteranos de guerra) ${ }^{38}$, y aunque su reintegración no fue fácil, los excombatientes estadounidenses formaron millones de nuevas familias, contribuyendo a una revalorización del hogar como centro íntimo y romántico de la vida del varón, y a la postre a la explosión demográfica (baby boom ${ }^{39}$. En cierto sentido, este emerger de la "masculinidad doméstica» ${ }^{40}$ se trató de una realización del ideal «descanso del guerrero", sin los excesos antifeministas del pasado europeo, en un mundo capitalista. Los valores culturales exportados desde los Estados Unidos que conquistaron la Europa Occidental ${ }^{41}$ también contenían un alto grado de glorificación de la experiencia bélica y de la figura del veterano de guerra, en un sentido claramente liberal, aunque definitivamente anticomunista. En la América del macartismo y la guerra de Corea, la prensa conservadora habi-

\footnotetext{
Fotos, 27 de octubre de 1945.

Gambone (2005).

Frydl (2009).

Patterson (1996): 14; Van Ells (2001): 57-94, 209-243.

Rutherdale (1999)

41 De Grazia (2005).
} 
tualmente asociaba la masculinidad viril con el anticomunismo, mientras el cine retrataba a los comunistas como afeminados ${ }^{42}$. Así, los nuevos modelos de masculinidad y paternidad que llegaban a España, sobre todo a través de Hollywood $^{43}$, tenían puntos de enlace con esa generación de excombatientes franquistas que, al igual que FET-JONS, comenzaba a ver restaurado su lugar político y social en el régimen a comienzos de los años cincuenta. La película Los mejores años de nuestra vida (William Wyler, 1946), que describía de manera muy endulzada los problemas de reintegración emocional y familiar de veteranos de guerra norteamericanos, llenó las salas de cine españolas durante varios meses desde finales de 1947, y recibió críticas muy positivas ${ }^{44}$. Por estas vías, en la década de los cincuenta los modelos masculinos del cine estadounidense, sustancialmente patriarcales ${ }^{45}$, encontraron calado en España.

Otros ideales yanquis de masculinidad llegaron al país con la americanización económica española, la cual, si todavía estuvo muy refrenada en el contexto de la autarquía, fue evidente sobre todo desde 1953, tras la firma de los pactos militares y económicos entre Franco y Eisenhower. Los empresarios españoles ya habían comenzado a modernizarse a imagen del ejemplo estadounidense, por vías directas o indirectas, desde la segunda mitad de los años cuarenta ${ }^{46}$. José Luis Castro Vázquez de Prada, un periodista falangista nacido en 1912 en la provincia de Valladolid ${ }^{47}$, representa a la perfección esa evolución del arquetipo de masculinidad excombatiente en los años cincuenta, esa nueva identidad de "hombre de negocios» que se empezaba a asumir entre las elites sociales de la dictadura. En su revista Dólar, fundada a finales de 1951, Castro Vázquez de Prada pretendía explícitamente promover entre los españoles «la actitud juvenil» del hombre de negocios norteamericano - «siempre dinámico, risueño, vehemente»-, pero respetando los «matices peculiares» de la idiosincrasia española ${ }^{48}$. Eso significaba refundir las viejas actitudes e ideas de raíz fascista y con olor a pólvora en modelos nuevos; una reconversión de esquemas mentales: en Dólar se entrevistó al afamado psiquiatra militar

42 Patterson (1996): 239 y 255.

43 Niño (2012): 234.

44 Radiocinema, núm. 142 (diciembre de 1947). La Vanguardia Española (Barcelona), 28 de diciembre de 1947.

45 Bruzzi (2005).

46 Puig y Álvaro (2002) y Puig (2003).

47 Una semblanza de este personaje en $A B C, 13$ de noviembre de 1970. En 1939, Castro había escrito un libro sobre el «Movimiento Nacional» en Palencia: Castro Vázquez de Prada (1939).

48 Dólar. Brújula de los negocios (Madrid), núm. 1 (diciembre de 1951). 
Vallejo-Nájera, al que se le preguntó si podía existir también una especie de «psicosis de guerra» producida por el «dinamismo agotador» de la actividad mercantil y financiera ${ }^{49}$. También en la revista se ensalzó la «elegante» elocuencia y la figura de José Antonio Girón, ministro de Trabajo y todavía delegado nacional de Excombatientes de FET-JONS, y de casi idéntica edad y procedencia que Castro Vázquez de Prada (y de hecho el viejo fascista excombatiente Girón se transformaría con los años en un empresario inmobiliario). Más aún, la revista Dólar inquirió al propio Ernesto Giménez Caballero, parece que en busca de su aprobación, si despreciaba al hombre de negocios, pero aquel intelectual, pionero del fascismo en España, confirmó positivamente que no: «Para ser hombre de negocios de verdad», dijo Gecé, «se necesita más corazón que para ser torero, militar y paracaidista. [...] Admiro al hombre de negocios. [...] Veo en él el calvario heroico de un padre. [...] Debería haber laureadas para esos hombres bravos, machos, excepcionales. [...] El verdadero hombre de negocios es un poeta, un soñador, un creador ${ }^{50}$. Como vemos, el ideal de masculinidad excombatiente franquista se reformaba, y los viejos valores y lenguajes de la guerra y la «Revolución Nacional» se aplicaban a nuevos fines empresariales: «Voluntad, trabajo, fe», para «ganar la batalla por la venta $»^{51}$.

Con esos nuevos influjos de los años cincuenta cambiaban también las modas en el vestir, las pautas de consumo y los modales. Nuevas nociones de elegancia masculina, exentas de excesivo atildamiento, y con un aire más práctico y deportivo, también contribuían a transformar los ideales de hombría. A los maridos, «jefes de la familia» según explicaba un manual de etiqueta de 1946, les agradaba «representar en el teatro de la vida el papel de héroes, grandes, fuertes, silenciosos, estoicos», pero a la vez necesitaban ser halagados por sus esposas, tratados como «un niño cuando está enfermo $»^{52}$. En 1955, un desenfadado artículo en una revista internacional de excombatientes comentaba la pérdida de prestigio del uniforme entre los hombres y mujeres; de estas, un $77 \%$ ya prefería a los varones vestidos de civil $^{53}$. Pero en la España de Franco todavía el «estilo militar de vida» demostraba fortaleza, haciendo vigentes las «virtudes militares» de subordinación, disciplina, humildad, y también de la

\footnotetext{
49 Ibid.

50 Dólar, núm. 2 (enero de 1952). La cursiva sobre la medalla laureada es mía.

51 Dólar, núm. 6 (junio de 1952) y núm. 15 (marzo de 1953).

52 Padovani (1946): 17 y 59; Farnese (s. f.). También la Iglesia católica española defendía en esas fechas la figura del padre como «autoridad» y «jefe» del hogar, véase Tarancón (1958): 99-101.

53 Anciens Combattants du Monde (Paris), núm. 56 (noviembre de 1955).
} 
austeridad y la evitación del lujo ${ }^{54}$. No fue fácil superar el antiamericanismo de falangistas, católicos y, sobre todo, militares franquistas que despreciaban a los Estados Unidos como país carente de auténticos valores militares, y cuyas victorias — decían - solo habían sido posibles gracias a la tecnología ${ }^{55}$; ciertos grupos e individuos como el propio Millán Astray, a pesar de la creciente influencia norteamericana, nunca abandonarán del todo los viejos ideales, incluidas autorepresentaciones de la virilidad castrense ${ }^{56}$.

En cualquier caso, la idea fuerza del «descanso del guerrero» todavía permite entender esa hegemónica masculinidad franquista de la generación combatiente, caracterizada en los años cincuenta por la combinación de elementos viejos y nuevos. En los hogares, sobre todo en los urbanos, nuevas comodidades y placeres para la vida comenzaban a cobrar más importancia. La segunda mitad de la década de los cincuenta es la del ascenso de los electrodomésticos como objetos codiciados por la sociedad española; un culto que se dispararía exponencialmente en la primera mitad de los sesenta ${ }^{57}$. Pero otros bienes de consumo ya venían atrayendo a los varones de mediana edad, como productos que debían ser bien apreciados por los verdaderos hombres. No solo anuncios con fuertes connotaciones viriles de botellas de coñac en la prensa (sobre todo en fechas navideñas), junto a los de productos contra la caída del cabello, solicitaban la atención de varones que al envejecer buscaban sabores fuertes y añejos con los que ya se había combatido el frío en las trincheras de la Guerra Civil («Si pide veterano beberá un buen coñac Osborne») ${ }^{58}$; también los cigarros puros y, sobre todo, el whisky, como reconocía el escritor falangista y excombatiente Rafael García Serrano, conquistaban los paladares de aquellos cuarentones $^{59}$. En ese periodo, la emergencia de una sociabilidad excombatiente en forma de hermandades implicó la participación esporádica de veteranos de guerra franquistas en reuniones y banquetes con antiguos «camaradas», donde se degustaban los goces del comer, del beber y del fumar en un ambiente cas-

54 Vigón (1953): 55.

55 Fernández de Miguel (2006).

56 La cuestión de la masculinidad de los «Caballeros Mutilados» como Millán Astray en la España de Franco requeriría un estudio pormenorizado; véase de momento Wright (2016).

57 Esta apreciación se basa en la frecuencia y carácter de la propaganda sobre electrodomésticos en la prensa del periodo.

58 Estos anuncios se encuentran abundantemente en la prensa. La cita es del diario Marca en enero de 1950; la cursiva es mía. En 1956 Osborne adoptó la famosa y viril figura del toro como icono publicitario.

59 García Serrano (1959): 91. 
trense, intensamente masculino (imagen 2$)^{60}$. Pero, sobre todo, era en el hogar donde se esperaba que la esposa supiese servir al hombre el ansiado cóctel alcohólico relajante, tras un día de ejercer su profesión, peligrosa o no: en verdad, se buscaba otra vez el «descanso del guerrero», «el consuelo y la dulzura de pensar que tienen en su casa otra alma gemela, buena y dulce, que por ellos ora y espera ${ }^{61}$. Nuevos intereses como el vestir bien, a la moda de caballero, o placeres cotidianos «muy importantes», «como por ejemplo el fumar», seducían a los «sesudos hombres de la actual generación», «cansados [...] de tanta Guerra Fría» ${ }^{62}$.

\section{Imagen 2. Reunión de oficiales de la Guardia Civil, veteranos de la Cruzada, 1956}

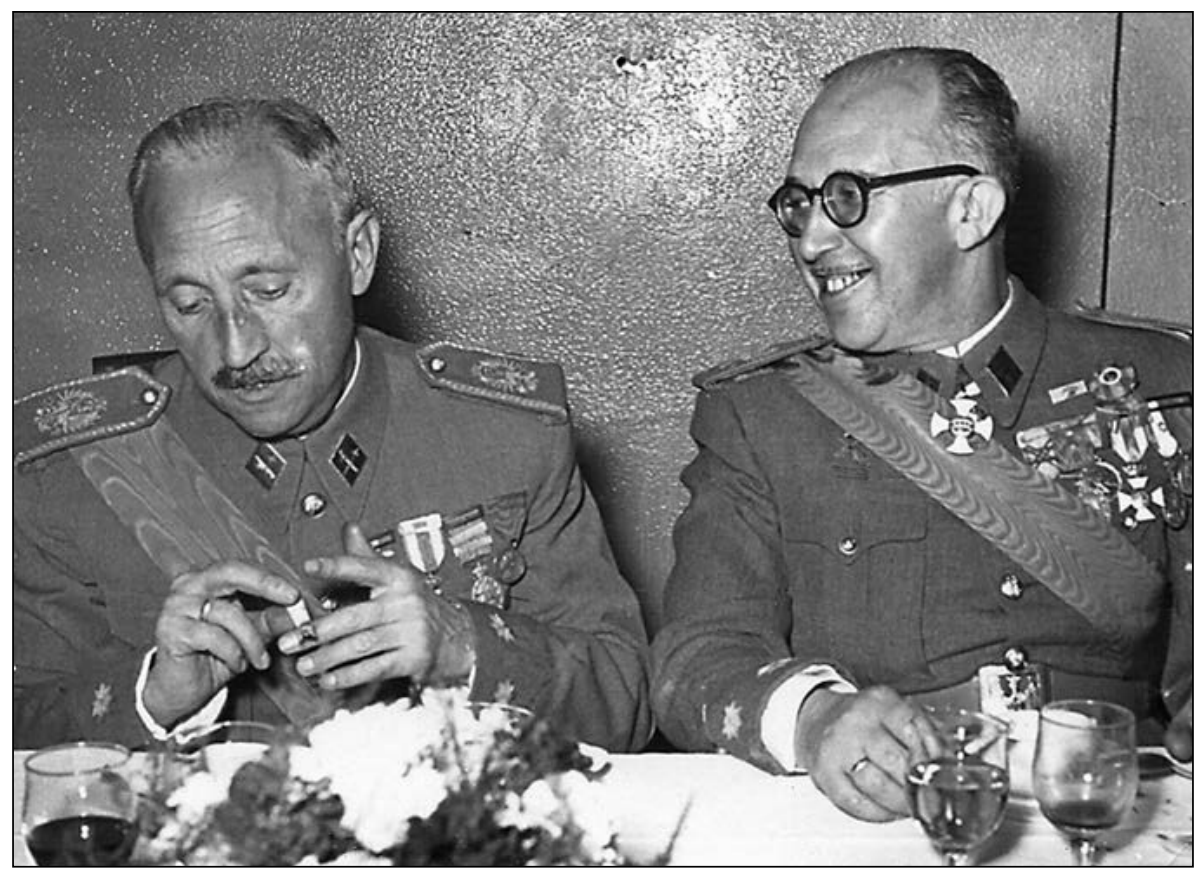

Fuente: archivo del autor.

60 Nótense medallas, anillos de matrimonio, copas, cigarro, bigotes, canas y alopecia, actitud de camaradería.

61 Señor. La Revista del Hombre (Barcelona), núm. 1 (noviembre de 1955).

62 Señor, núm. 2 (febrero de 1956). 
Durante la década de los cincuenta, los cambiantes ideales y autopercepciones masculinas de la generación de la guerra, cuyos miembros tenían unas edades que oscilarían entre los 28 y los 52 años, hubieron de incorporar definitivamente nociones de paternidad. No parece casual que fuese a mediados de los años cincuenta cuando en la España de Franco apareciese un subgénero cinematográfico llamado "cine con niño», donde se mostraban como protagonistas a tiernos infantes, en historias destinadas a un público más bien adulto: esta producción, de gran éxito comercial, seducía a una generación privilegiada de espectadores con hijos en esas mismas edades, o en otras palabras: una generación de veteranos de guerra franquistas que conservaba su masculinidad hegemónica en el régimen ${ }^{63}$. Controlar esa revalorizada esfera familiar de los individuos que habían conseguido la victoria de 1939 era importante para el régimen. En su mensaje de fin de año 1953 Franco afirmó que «la mayoría de los males del mundo" procedían «de la destrucción de los principios de la vida familiar ${ }^{64}$. En ese periodo, la imagen del dictador se exaltó no solo "como un capitán invicto», sino también como «un hombre inmaculado en su vida íntima y un padre ejemplar», publicándose fotografías hogareñas de Franco con su esposa y con niños ${ }^{65}$. En la prensa de esos años se localizan fácilmente reflexiones sobre las relaciones entre padres e hijos, que revelan las tensiones de la modernización de los modelos patriarcales ${ }^{66}$. Se criticaba la "pérdida de respeto por la vejez» ${ }^{67}$, pero a la vez parecía necesario suavizar los «desniveles espirituales» en el seno del hogar, existentes, por ejemplo, entre un padre serio, trabajador, encerrado en su despacho, y niños que juegan y hacen ruido «al otro extremo de la casa» ${ }^{68}$. Normalmente, el cabeza de familia, en su rol de breadwinner todavía limitaba su participación directa en los asuntos del hogar, dejados al arbitrio de la esposa, salvaguardando así el espacio de su solaz: el padre solía entregar a su mujer la mayor parte de su sueldo, salvo una

63 La comedia Recluta con niño (Pedro Luis Ramírez, 1955) hábilmente mezclaba una temática militar con el tema infantil. Sobre el subgénero véase, por ejemplo, Pérez-Gómez (2010).

64 Amanecer (Zaragoza), 1 de enero de 1954.

65 La cita es de $A B C, 1$ de octubre de 1958, donde se publica una fotografía en la que Franco aparece posando con su esposa y - creemos identificar-cuatro de sus sobrinos.

66 Pueyo Longás (1955): 7.

67 Dr. C. Blanco Soler: «Familia, familia...», $A B C$ (Sevilla), 9 de julio de 1959.

68 Francisco Javier Martín Abril: «Desniveles espirituales», $A B C, 1$ de septiembre de 1954. Véase también P. Félix García: «Padres e hijos», $A B C, 8$ de agosto de 1958; P. Félix García: «Hijos y padres», $A B C, 6$ de septiembre de 1958. 
fracción para sus propios gastos de "tabaco», «transporte, comprar el periódico y, cuando tengo que acudir a la cita de algún amigo, tomar café»" ${ }^{69}$, pero la creciente presencia infantil en las vidas de esa generación de excombatientes era difícil de ignorar. En un poroso periodo entre mediados de los años cincuenta y mediados de los sesenta, el modelo ideal de masculinidad excombatiente franquista debía incorporar necesariamente elementos paternales, pues muchos de los hijos e hijas de aquel colectivo se encontraban en la segunda infancia, pubertad o adolescencia. Probablemente, sin embargo, aquel reforzamiento de papeles familiares contribuyó a desgastar el filo de los antiguos modelos más agresivos de masculinidad y a socavar la tranquilidad del descanso del guerrero.

\section{LOS AÑOS SESENTA}

Como se ha puesto de relieve recientemente, los años sesenta supusieron una etapa de crisis identitaria para lo que entonces comenzó a entenderse como la "generación del 36». Las transformaciones del desarrollismo tras la liberalización económica de 1959, la reinvención de la memoria de la guerra en torno a las celebraciones de los «25 años de paz», y la emergencia de nuevas elites políticas como los tecnócratas del Opus Dei acompañaron a la profunda transformación del movimiento excombatiente franquista, marcada sobre todo por la aparición de las Hermandades de Alféreces Provisionales. Los hombres que formaban esta nueva fuerza política excombatiente eran grupos sociales privilegiados: antiguos exalféreces y exoficiales franquistas que habían desarrollado normalmente exitosas carreras profesionales y ostentaban un perfil sociológico de clase media-alta ${ }^{70}$. Solamente entre 30000 y 50000 hombres se habían formado como alféreces provisionales durante la guerra, así que en los años sesenta aquellos supervivientes representaban una elite muy reducida de la sociedad española. Era un grupo, no obstante, muy influyente, acaudalado y objeto de mucha atención mediática. En lo que a modelos de masculinidad se refiere, ellos encarnaban el ideal del varón franquista en los años sesenta por encima de cualquier otra representación modélica de virilidad, salvo acaso la del propio Franco y otros jerarcas del régimen. Pero precisamente, al tratarse de grupos que habían dejado bien atrás la juventud, la insistencia en el ideal masculino del veterano de guerra resultaba problemática

69 «Un padre de familia numerosa», $A B C$ (Madrid), 10 de abril de 1956; también $A B C$ (Sevilla), 31 de diciembre de 1957.

70 Alcalde (2014): 327-243. 
y contradictoria en un régimen que trataba de renovarse para perpetuarse, justamente hablando menos de guerra y más de paz.

La historia del ideal de masculinidad excombatiente franquista en esta década es la historia de esas contradicciones. El proceso biológico de envejecimiento de quienes siendo jóvenes o muy jóvenes habían combatido y vencido una guerra - de quienes se habían hecho a la idea de haber sido los verdaderos y casi únicos artífices, autores, responsables de la victoria bajo las órdenes de Franco-y cuyos éxitos en el cumplimiento de ese deber castrense se habían corroborado con el triunfo profesional, emocional y sexual durante y después de la guerra, era un proceso traumático inescapable al que se le debía dar sentido. Las publicaciones de las hermandades de alféreces provisionales insistían en que sus miembros, al cabo de veinte años, seguían siendo los mismos del 36: a la fe, el entusiasmo, el valor de veinteañeros habían agregado veinte años de experiencia ${ }^{71}$. Se exaltaba la madurez de aquellos hombres de entre cuarenta y cincuenta años, afirmando que podían ahora «rendir sus mejores frutos $»^{72}$. La reconversión del ideal de masculinidad excombatiente franquista, pues, respondió a las necesidades de hombres que se sentían envejecer; a medio plazo, fue una respuesta a la «crisis de la mediana edad» de muchos de ellos ${ }^{73}$. Esto fue posible porque, como se ha empezado a demostrar en los estudios sobre masculinidades, los hombres mayores también pueden mantener un discurso de "masculinidad hegemónica» a pesar de las tensiones implícitas en el factor edad ${ }^{74}$. En la década de los sesenta, los excombatientes franquistas luchaban para conservar su «descanso de guerreros» tanto en la esfera pública como en el seno de sus hogares.

Caracterizaré ahora sucintamente ese modelo ideal de hombre que aquellos individuos intentaban construir, emular y realizar. La mayoría de

71 Cruzada. Boletin Informativo de la Hermandad Provincial de Alféreces Provisionales (Ávila), núm. 2 (octubre de 1959). Arriba, 30 de mayo de 1958.

72 Boletín de la Hermandad Nacional de Alféreces Provisionales (Madrid), núm. 2-3 (diciembre de 1961).

73 Por crisis de la mediana edad (midlife crisis) puede entenderse un «mal psicológico propio de la sociedad contemporánea, caracterizado por el ensimismamiento, ansiedad, y por la creencia, en personas con una profesión, de que puede que hayan alcanzado su cumbre en términos ocupacionales y de satisfacción vital, pero que el futuro probablemente depare más frustraciones que logros. Esto puede predisponer o precipitar desórdenes emocionales». Traducción mía de Last (2007): ad nomen. Sobre la crisis de la mediana edad en relación con los ideales burgueses de masculinidad en el siglo XX véase el análisis literario de Bauer (2015).

74 Bartholomaeus y Tarrant (2015). 
elementos que se yuxtaponen al ideal masculino del franquista de la "generación del 36» son los mismos que se habían ido añadiendo durante los años cincuenta, como hemos visto, a los vestigios de esa masculinidad guerrera de inspiración fascista de comienzos de los cuarenta. Hemos comentado ya las pautas de consumo, ocio y moda, que solieron mantenerse, refinarse y perfeccionarse con la edad. El arquetipo masculino de varón franquista en los años sesenta — según debería rezar una narrativa retrospectiva de su trayectoria ideal - era el antiguo combatiente que había tenido hombres bajo su mando durante la Guerra Civil, obtenido distinciones militares y derramado su sangre a consecuencia de heridas en el conflicto; en la posguerra habría formado una familia con una esposa - quizá educada, pero dedicada primordialmente a las labores del hogar-y engendrado numerosos hijos, así como desarrollado exitosamente una profesión de prestigio o negocio lucrativo. Si se habían albergado ideas políticas «revolucionarias» (fascistas), esos ardores se habían quizá atemperado en la segunda mitad de los años cuarenta, a veces abrazando brevemente una actitud de quijotismo («si ellos tienen ONU, nosotros tenemos dos», habían afirmado algunas pancartas, según decía recordar Rafael García Serrano a finales de los cincuenta) $)^{75}$, pero sobre todo reforzando la autopercepción como creyentes católicos: la asistencia ostentosa a misa en los años cincuenta y sesenta, y la participación solemne en rituales religiosos también debe verse como parte de ese proceso de autoconstrucción de un ideal viril (las reuniones de excombatientes no solo celebraban comidas de hermandad, sino misas de campaña y en recuerdo a los caídos). Esos hombres en el seno de sus familias adoptaban una posición hierática, autoritaria, de mando, patriarcal como pueden haberla asumido en su vida profesional (idealmente dirigiendo una empresa), pero queriendo a la vez ejercer el papel de padres cariñosos, divertidos, asumiendo los nuevos modelos modernos de paternidad desarrollados en Occidente en las décadas centrales del siglo Xx, así como algunas prácticas de sociabilidad inspiradas en ejemplos norteamericanos. No hablaban mucho de la guerra a sus hijos, pero de la propia experiencia bélica ofrecían una versión mítica, encapsulada en fotografías o recuerdos que se atesoraban: una pistola, muy a menudo, guardada típicamente en el cajón de un despacho, era todo un símbolo (también con connotaciones viriles) cultivado por aquellos hombres, que daba sentido a esa masculinidad y rol paterno que se deseaba ejercer en el seno del «descanso del guerrero».

La relación con los hijos merece mayor comentario. La casuística en este sentido puede variar enormemente; a la altura de 1960, las edades de los hijos de la «generación del 36» (solo teniendo en cuenta los engendrados al

75 García Serrano (1959): 8. 
terminar la guerra) podría oscilar entre los cero y los veinte años. Pero por aquel entonces, probablemente la mayoría de descendientes de los antiguos soldados todavía estaba en la minoría de edad y, sin duda alguna, la mayor parte de los quizá millones de hijos de excombatientes franquistas ya había nacido. Por eso, como sujetos políticos, aquellos hombres debían ser entendidos ya no individualmente sino en conjunción con sus familias y, por tanto, se debía apelar a su masculinidad de manera que se incluyesen esas realidades. Baste mencionar la ensalzadora descripción que el diario falangista Arriba, en 1961, hizo de un desfile de excombatientes franquistas:

[...] no, no son arrogantes, ni fieros, ni jóvenes. No desfilan en correcta formación. No van uniformados. No saben ya llevar el paso marcial a los sones del metal épico y del tambor guerrero. Vienen con su tripa de cincuentones o con el rostro tostado a los soles de cincuenta veranos. No alzan la cabeza para que les vea la novia el laurel recién ceñido, sino para que le vean marchar sus hijos. [...] Son mis viejos camaradas. [...] Las calvas brillan como cascos. Los brazos desarmados se elevan en saludo de $\mathrm{paz}^{76}$.

Y en 1964, con ocasión del desfile militar de los «25 años de paz», de nuevo se encontró ocasión para describir a las multitudes del público, donde se veía a "veteranos de la guerra, que señalaban a sus hijos la unidad en que sirvieron o les explicaban el detalle de las armas» ${ }^{77}$. No obstante, las relaciones internas familiares de aquellos individuos podían no ser armónicas, llegando a amenazar la hegemonía masculina y patriarcal de ese colectivo.

Una serie de filmes y novelas contemporáneas o posteriores captan el cúmulo de conflictos internos existentes en las familias de esa generación, en el seno del hogar entendido como un «descanso del guerrero" que empezaba a ser perturbado. La novela Tormenta de verano (Juan García Hortelano, 1962) transmite ese mundo íntimo de hombres de negocios enriquecidos en la posguerra tras haber sido jóvenes combatientes de la Cruzada y que a comienzos de esta década se encontraban en una crisis identitaria y de masculinidad ${ }^{78}$. En la novela, el hallazgo del cadáver desnudo de una joven en la playa junto a la colonia de vacaciones en la que descansan varias de estas familias acomodadas desencadena recuerdos de la guerra conectados con la propia virilidad; en otras palabras, nostalgias por una masculinidad en plenitud.

76 Arriba, 18 de julio de 1961.

77 Arriba, 26 de mayo de 1964.

78 Pavlovic (2003): 49-70. 
-Es extraño, pero esa muchacha me ha recordado en un momento los días de Teruel, en el 37 — cambió la entonación y sonrió-. Cuando tú me sacaste de aquel infierno, me llevaste a San Sebastián y me dejaste en el más cálido prostíbulo de toda Europa con la mujer más gorda de todo el mundo ${ }^{79}$.

Entre veladas amistosas con constante consumo de whisky, ginebra, vodka o coñac, los personajes evidencian su crisis identitaria y de masculinidad:

Toda mi vida he conseguido lo que me apetecía y ahora no me voy a quedar sin lo que quiero. Lo de estos veinte años ha estado bien, de acuerdo. Hicimos la guerra, la ganamos y nos pusimos a cuadruplicar el dinero que tenían nuestras familias antes del 36. Pero basta ya. Cuadruplicando dinero, teniendo hijos, yendo a cenar y a fiestas, echándome queridas y aguantando idiotas para conseguir permisos de importación o contratos del ochenta por ciento, he perdido de vista otras $\operatorname{cosas}^{80}$.

La autopercepción de los protagonistas varones de Tormenta de verano otorga una enorme importancia al hecho de haber combatido la guerra y de haber continuado trabajando con éxito en el periodo posbélico (lo que corresponde a haberse adaptado a los cambiantes modelos de masculinidad que hemos analizado más arriba), legitimando así su exigencia de poder disfrutar ahora del merecido "descanso del guerrero»:

- [...] En el 36 yo tenía veinticuatro años y luché desde el primero hasta el último día. Gané dos medallas individuales y tres colectivas. Empecé de alférez provisional y acabé de capitán. En el 39 me puse a trabajar...

- Por favor, don Javier, no desconozco que es usted una persona honorable.

- Me puse a trabajar como una mula y he hecho algo, y bastante importante, en la reconstrucción de la patria. He dado trabajo a cientos y cientos de hombres, he creado empresas, he traído y llevado materias primas, he aumentado la riqueza ${ }^{81}$.

Si en Tormenta de verano los hijos de esos excombatientes hombres de negocios no juegan todavía un papel central, en la novela de Miguel Delibes El principe destronado (publicada en 1973, pero ambientada a comienzos de

79 García Hortelano (1992): 18-19.

80 García Hortelano (1992): 257.

81 García Hortelano (1992): 298-299. 
los sesenta), la clave son las relaciones, en el corazón de un hogar de clase media-alta, entre un padre perteneciente a la "generación del 36», su esposa, y los hijos a quienes el hombre desea transmitir de manera autoritaria sus propios valores ideológicos. Mientras el mayor, de dieciséis años, es reacio a participar en las ceremonias patrióticas que desea su padre, el hijo pequeño demuestra tener una percepción lúdica de «la guerra de papá», inculcada por su progenitor ${ }^{82}$. La esposa (hija de un antiguo republicano sobre el que el marido, furioso, afirma que habría que haberle cerrado «la boca a tiempo, en lugar de andar con tantas contemplaciones») reprueba que su esposo quiera regalarle al niño un tanque de juguete. "Lo malo», afirma el padre, «es si alguien piensa que al regalarte un tanque te estoy inculcando sentimientos belicosos. Hay personas que prefieren hacer de sus hijos unos entes afeminados antes que verles agarrados a una metralleta como hombres» ${ }^{83}$. En 1966, la película Siete cartas a Berta (Basilio Martín Patino) también captó ese choque generacional e incipientemente ideológico entre padres excombatientes franquistas y sus hijos.

Fue entonces, probablemente, cuando la nostalgia comenzó a consolidarse como una emoción implícita en la identidad masculina de los componentes del movimiento excombatiente franquista, quienes, «en la tranquilidad de los hogares», empezaban a acariciar los recuerdos de "aquel constante desafío de muerte, que por doquier acechaba» y aquellas "chabolas» del frente, que hacían "casi la orgía dorada de nuestra felicidad $»^{84}$. Ya a comienzos de los años cincuenta, como en aquel I Congreso Nacional de Excombatientes del Alto de los Leones, el régimen había buscado agitar las añoranzas de ese colectivo social en busca de beneficios políticos ${ }^{85}$; y la melancolía sin duda fue otro sentimiento clave en el éxito - desde mediados de esa década - del movimiento asociativo de las Hermandades de la División Azul ${ }^{86}$. Pero la nostalgia como fenómeno sociológico más generalizado llegó posteriormente, coincidiendo con el ascenso de esa emoción en las sociedades occidentales durante los años setenta. Para la generación de excombatientes franquistas, en nuestra opinión, esa emoción también se originó en el seno de los hogares ante el crecimiento de los propios hijos, que al avanzar

82 Delibes (1986): 15. La novela fue adaptada al cine con el título La guerra de papá (Antonio Mercero, 1977).

83 Delibes (1986): 75.

84 Cruzada. Boletín Informativo de la Hermandad Provincial de Alféreces Provisionales, núm. 3 (enero de 1960).

85 Alcalde (2014): 279.

86 Sobre la memoria de la División Azul, véase Núñez Seixas (2005, 2016: 345-402). 
hacia la adultez abandonaban los modelos ideales heredados de los padres ${ }^{87}$, lo cual hizo que a menudo la nostalgia derivase en desencanto. Nostalgia y desencanto, por supuesto, no eran elementos explícitamente presentes en el arquetipo de masculinidad excombatiente franquista; eran, más bien, emociones conectadas con la crisis de la mediana edad, que empujaban a intentar reforzar y blindar la hegemonía del ideal varonil de esa generación. Al participar, junto a sus iguales, en conmemoraciones y actos para mostrar su persistente adhesión al Caudillo, aquellos hombres de los años sesenta sentían entusiasmarse por su «extraño rejuvenecimiento»"

Pero la verdad es que se trataba de una masculinidad en entredicho y en definitivo declive. ¿Cómo afectó aquello a las relaciones de género, entre maridos y mujeres? En los sectores más católicos se insistía todavía en que las esposas debían reforzar su rol tradicional, en un momento de crisis en la familia ${ }^{89}$. Se decía que la mujer tenía que tener indulgencia para amar a un cónyuge que se había vuelto diferente con los años: «El hombre es de oro cuando novio, de plata cuando esposo, de hierro cuando marido»; «Maridos hay que se manifiestan llenos de nostalgia por los amigos, y son regañones y de mal contentar; dan suspiros detrás de las paredes domésticas, como soberanos en destierro» ${ }^{90}$. Con comprensión por esa crisis de la mediana edad, la mujer podía todavía salvaguardar el justo «descanso del guerrero».

Con todo, en la segunda mitad de los años sesenta, el paradigma de masculinidad excombatiente franquista alimentado por dicha idea fuerza claramente perdió su hegemonía, por mucho que sectores inmovilistas del régimen, cada vez más decrépitos, lo pretendiesen conservar como parte de su universo ideológico. De nuevo, modernos modelos de masculinidad procedentes de fuera del país ejercieron un papel clave, esta vez para desbancar finalmente a los antiguos. Aunque en el NODO y en la prensa se comentase con sorna la visita de los Beatles a España en 1965, la realidad era que semejantes imágenes juveniles de los «melenudos mocitos de Liverpool», que arrastraban a las masas yeyé, difícilmente se podían armonizar con lo que la «generación del 36» quería representar ${ }^{91}$. En los Estados Unidos el modelo

87 Sobre la nostalgia y sobre la mediación de la relación paterno-filial entre el individuo y el pasado, véase Lowenthal (1985): 4-13, 51, 71.

88 Cruzada. Boletín Informativo de la Hermandad Provincial de Alféreces Provisionales, núm. 4 (julio de 1960).

89 Redondet y López Doriga (1960).

90 Lamera (1961): 63.

${ }^{91} A B C, 4$ de julio de 1965. Filmoteca Española, NOT N 1175 B, 12 de julio de 1965. 
hegemónico de masculinidad también se rejuveneció, encarnado oficialmente por John F. Kennedy (aunque también se tratase de otro heroico veterano de guerra), cuya imagen integraba elementos del «rebelde quinceañero» y del playboy ${ }^{92}$. La revitalización del valor de la juventud en Occidente, clara hacia finales de los sesenta, con nociones de masculinidad juvenil menos viriles y más orientadas al consumo ${ }^{93}$, fue un fuerte golpe a la hegemonía del ideal del excombatiente en España. El mitificado descanso del guerrero empezó a mostrar grietas. Las aspiraciones femeninas a una mayor libertad condujeron a plantear que el hombre no solamente debía disfrutar del solaz en casa, sino también colaborar en tareas domésticas: tímidamente se comenzaba a reconocer la legitimidad de que la mujer pudiese exigir descanso en el hogar, tras «una jornada de trabajo muy dura», y que el marido lo comprendiese, diciendo: «Dime lo que puedo hacer mientras tú descansas un poco»" No hay que exagerar estas fisuras, no obstante: los años sesenta vieron la consagración en el cine español del modelo de género de «feliz madre y ama de casa», que emergió junto al modelo masculino del «abuelo bonachón»". Así, el tiempo y la progresiva entrada en la vejez de los varones que habían combatido en la Guerra Civil hicieron surgir otro tropo muy diferente al del «descanso del guerrero», el muy popular de las «batallitas del abuelo», originado en la figura cómica de la familia Cebolleta (diseñada por el dibujante Manuel Vázquez desde 1951) y aplicado a aquellos ancianos que insistían en hablar de sus experiencias de la Cruzada y se les hacía oídos sordos en casa, lo cual deja entrever los roles masculinos significativamente diferentes que la "generación del 36», despojada ya de su hegemonía, asumiría en las familias españolas a partir de la Transición. De esta manera lo auguraba ya en 1968 el escritor catalán Ángel Carmona Ristol, al comentar el envejecimiento de los miembros de las Cortes franquistas, que recién acabada la guerra habían pretendido instaurar una paidocracia o "gobierno de los jóvenes»:

El joven que hace un mito de lo que tan solo es situación transitoria, acabará, sin saber cómo, descubriéndose un día en el triste papel de viejo verde o «abuelo batallitas» de las historietas cómicas. Contra el orgullo juvenil, hay en el tiempo un enemigo implacable que, frente a la soberbia de ayer, moviliza la de las nuevas generaciones ${ }^{96}$.

\footnotetext{
92 Dominguez Andersen (2015).

93 Tinker (2014).

94 Blanco y Negro (Madrid), 24 de octubre de 1964.

95 Rincón (2014).

96 La Vanguardia Española, 17 de enero de 1968.
} 


\section{CONCLUSIÓN}

En esta perspectiva relativamente larga sobre la evolución del ideal de masculinidad excombatiente franquista he argumentado que este modelo fue hegemónico durante la mayor parte del régimen. Como ha sido puesto de relieve por los teóricos de las masculinidades, el concepto de «masculinidad hegemónica» debe entenderse no solo como identidad o como conjunto de expectativas en los roles de género, sino también como patrón de conducta y prácticas que permiten mantener la dominación de los hombres sobre las mujeres. Además, la masculinidad hegemónica, que no es la más habitual en sentido estadístico, sino que suele ser representada por una minoría, es «normativa ${ }^{97}$, e implica relaciones jerárquicas y de dominio sobre otros hombres y otras masculinidades; es decir, ejerce una «hegemonía interna» en el conjunto de varones de una sociedad ${ }^{98}$. No obstante, sometida a la competencia de otras masculinidades y enfrentada al cambio histórico, la masculinidad hegemónica puede transformarse a través de procesos de hibridación, para mantener su posición dominante. Como he intentado demostrar con este artículo, esta teoría se corrobora a través del caso empírico analizado.

Pero, ¿cuál fue, en todo periodo, la característica esencial de la masculinidad excombatiente franquista? Responder a esto también nos permite entender por qué aquella fue hegemónica en buena parte de la dictadura. En primer lugar, ha de tenerse en cuenta que la masculinidad excombatiente era algo diferente a la masculinidad castrense o de guerra; aunque relacionado, era algo distinto a esos modelos y a la exaltación del soldado y del combatiente propia de la movilización para una guerra total como la de 1936-1939. El régimen de Franco, ciertamente, nació de la guerra, pero pretendió perpetuarse en una sociedad en estado de "paz». Fue el hecho de haber atravesado el rito de paso del servicio de armas ${ }^{99}$, de haber cumplido con esa función de contribuir a la victoria fundacional de la «nueva España», el elemento clave que se potenció para definir un modelo de masculinidad hegemónico que a su vez contribuiría a consolidar la dominación del régimen dictatorial. Esta se ejerció sobre todo sobre los vencidos, pero también sobre las mujeres, entendidas ante todo como vientres al servicio de la patria. Además, el énfasis en la experiencia de guerra, aunque relacionado con la ideología fascista, hacía posible coaligar

97 Connell y Messerschmidt (2005): 832.

98 Demetriou (2001) y Connell y Messerschmidt (2005): 845.

99 Durante la dictadura, el servicio militar obligatorio ejerció de sucedáneo de rito de paso bélico para los hombres españoles, con el cual también se pretendía configurar la masculinidad "patriótica» de las siguientes generaciones: véase Zulaika (1989). 
diversas opciones políticas que habían quedado fundidas en el franquismo durante el conflicto y, por tanto, permitía difuminar las divergencias en materia de género que podían albergar distintas culturas políticas, facilitando los equilibrios de poder.

He defendido que la idea fuerza que animó - - que permite adjetivaral concepto de masculinidad excombatiente franquista fue el famoso tropo del "descanso del guerrero», originado en la filosofía de Nietzsche, y cultivado implícita y a veces explícitamente por el antifeminismo y por la extrema derecha europea del primer tercio del siglo Xx, incluyendo el fascismo. Ese sintagma (lejos de ser un simple adorno o reclamo en el título de este artículo) es útil para el análisis histórico porque recoge, en una misma noción: primero, la experiencia bélica como rasgo identitario fundamental; segundo, las expectativas de recompensa que normalmente caracterizan a los veteranos de guerra $^{100}$ (en este caso en el ámbito íntimo y familiar); tercero, y al ser un tropo referido originalmente no al hombre sino a la mujer, el tipo de relaciones de género que idealmente debían establecerse entre varones y hembras; y cuarto, la dinámica de cambio identitario (de "guerrero» a «hombre que descansa») que permite explicar a medio y largo plazo la evolución e integración de nuevos elementos en dicho modelo de masculinidad.

Así, el «descanso del guerrero» de los excombatientes franquistas en la primera posguerra estuvo marcado por el éxito en la incorporación al trabajo y en la formación de células familiares, incluyendo la procreación y el nacimiento de hijos, como recompensa por el sacrificio bélico y confirmación de la virilidad demostrada en los campos de batalla. La crisis del final de la Segunda Guerra Mundial implicó temporalmente desacentuar la experiencia bélica como crisol de la masculinidad, pero también empezar a incorporar elementos nuevos a tal ideal viril: el disfrute de los toros y el fútbol, por ejemplo, se consolidaron como rasgos característicos de un arquetipo masculino todavía sustancialmente violento. Estas prácticas de ocio, además, también tenían relación con la noción del descanso tras la guerra, propia de la identidad excombatiente. En los años cincuenta, con la Guerra Fría, y de la mano del anticomunismo, no solo pudo rehabilitarse la identidad excombatiente, junto al falangismo, sino que también pudieron abrazarse modelos norteamericanos sin complejos. Sobre todo, la fusión de la masculinidad hegemónica excombatiente franquista con el nuevo ideal del «hombre de negocios» de sabor yanqui, contribuyó a restablecer el lugar privilegiado del colectivo de hombres que habían hecho la guerra, convertidos ahora en padres y profesionales de prestigio. Definitivamente, el ideal de

100 Sobre esto véase Barrois (1993); Crotty y Edele (2013). 
hombre con experiencia de combate se diluyó, pero no se evaporó, con el énfasis en el rol patriarcal y paternal de los varones españoles en la sociedad franquista de los años cincuenta, mientras se conservaba en lo fundamental su posición dominante en el seno de hogares cada vez más cómodos materialmente. En los años sesenta, sin embargo, la masculinidad excombatiente franquista entró en crisis y en definitivo declive. La principal razón de esto era simplemente el paso inexorable de los años: el envejecimiento traumático de la «generación del 36» provocó reacciones defensivas que intentaban conservar la hegemonía del ideal de virilidad, pero que fracasaron a la postre en este objetivo. En ese momento, el orden sociofamiliar que había implantado el franquismo desde la guerra civil, y que tuvo un puntal en el ideal de masculinidad excombatiente franquista, empezó a resquebrajarse. Las nuevas familias de la sociedad española no darían continuidad a la valoración positiva de la experiencia bélica como rasgo de masculinidad que el franquismo había cultivado durante décadas.

\section{Bibliografía}

Alcalde, Á. (2013). Experiencia de guerra y relaciones de género: los excombatientes franquistas de la guerra civil española. En T. M. a Ortega López y M. Á. del Arco Blanco (eds.). Claves del mundo contemporáneo, debate e investigación: Actas del XI Congreso de la Asociación de la Historia Contemporánea. Granada: Comares (Cd-rom).

- (2014). Los excombatientes franquistas. La cultura de guerra del fascismo español y la Delegación Nacional de Excombatientes (1936-1965). Zaragoza: Prensas de la Universidad de Zaragoza.

- (2015). Los orígenes de la Delegación Nacional de Excombatientes de FET-JONS: la desmovilización del ejército franquista y la Europa de 1939. Ayer, 97, 160-194.

Aresti, N. (2012). Masculinidad y nación en la España de los años 1920 y 1930. Mélanges de la Casa de Velázquez, 42 (2), 55-72.

- (2014). The Battle to Define Spanish Manhood. En Morcillo, A. (ed.). Memory and Cultural History of the Spanish Civil War. Realms of Oblivion (pp. 147-177). Leiden/ Boston: Brill.

Barrois, C. (1993). Psychanalyse du Guerrier. Paris: Hachette.

Bartholomaeus, C. y Tarrant, A. (2015). Masculinities at the Margins of «Middle Adulthood»: What a Consideration of Young Age and Old Age Offers Masculinities Theorizing. Men and Masculinities, en prensa.

Bauer, E. K. (2015). Masculinity in Crisis: Aging Men in Thomas Mann's "Der Tod in Venedig» and Max Frisch's Homo faber. The German Quarterly, 88 (1), 22-42. Disponible en: https://doi.org/10.1111/gequ.10224.

Bourke, J. (1996). Dismembering the Male. Men's Bodies, Britain and the Great War. London: Reaktion Books. 
- (2008). Sed de sangre. Historia intima del combate cuerpo a cuerpo en las guerras del siglo $X X$. Barcelona: Crítica.

Bruzzi, S. (2005). Bringing Up Daddy. Fatherhood and Masculinity in Post-war Hollywood. London: BFI Publishing.

Cabanes, B. y Piketty, G. (2009). Retour à l'intime au sortir de la guerre. París: Tallandier.

Cachinero Sánchez, B. (1982). La evolución de la nupcialidad en España (1887-1975). Reis: Revista española de investigaciones sociológicas, 20, 81-100. Disponible en: https://doi. org/10.2307/40182923.

Castro Vázquez de Prada, J. L. (1939). Resurgir: episodios y anécdotas del Movimiento Nacional de Palencia. S. 1.: s. e.

Cazorla, A. (2015). Franco. Biografía del mito. Madrid: Alianza.

Cenarro, Á. (2006). Movilización femenina para la guerra total (1936-1939): un ejercicio comparativo. Historia y Política, 16, 159-182.

Confederación Católico Nacional de Padres de Familia (1940). Reintegración del Espíritu de la Familia Cristiana en España. Bilbao: s. e.

Connell, R. W. y Messerschmidt, J. W. (2005). Hegemonic Masculinity: Rethinking the Concept. Gender and Society, 19 (6), 829-859. Disponible en: https://doi. org/10.1177/0891243205278639.

Corbin, A., Courtine, J.-J. Vigarello, G. (eds.) (2011). Histoire de la virilité. 3 vols. París: Seuil.

Crotty, M. y Edele, M. (2013). Total War and Entitlement: Towards a Global History of Veteran Privilege. Australian Journal of Politics and History, 59 (1), 15-32. Disponible en: https://doi.org/10.1111/ajph.12001.

Crouthamel, J. (2014). An Intimate History of the Front. Masculinity, Sexuality and German Soldiers in the First World War. Basingstoke: Palgrave Macmillan. Disponible en: https://doi.org/10.1057/9781137376923.

De Grazia, V. (2005). Irresistible Empire: America's Advance Through Twentieth-Century Europe. Cambridge (MA): Belknap Press of Harvard University Press.

Delibes, M. (1986). El principe destronado. Barcelona: Destino.

Demetriou, D. Z. (2001). Connell's Concept of Hegemonic Masculinity: A Critique. Theory and Society, 30 (3), 337-361. Disponible en: https://doi.org/10.1023/A:1017596718715.

Dominguez Andersen, P. (2015). The Hollywood Beach Party Genre and the Exotification of Youthful White Masculinity in Early 1960s America. Men and Masculinities, 18 (5), 511-535. Disponible en: https://doi.org/10.1177/1097184X14558880.

Donaldson, M. (1993). What is Hegemonic Masculinity? Theory and Society. 22 (5), 643-657.

Ducanson, C. (2015). Hegemonic Masculinity and the Possibility of Change in Gender Relations. Men and Masculinities, 18 (2), 231-248. Disponible en: https://doi. org/10.1177/1097184X15584912.

Farnese, Willy. (s. f.). El auténtico señor. Tratado de etiqueta de la alta sociedad. Barcelona: Mateu.

Fernández de Miguel, D. (2006). El antiamericanismo en la España del primer franquismo (1939-1953): el Ejército, la Iglesia y Falange frente a Estados Unidos. Ayer, 62, 257-282.

Fouchard, D. (2013). Le poids de la guerre. Les poilus et leur famille après 1918. Rennes: Presses Universitaires de Rennes. 
Frydl, K. J. (2009). The GI Bill. Cambridge: Cambridge University Press.

Gallego, F. (2014). El evangelio fascista. La formación de la cultura politica del franquismo (1930-1950). Barcelona: Crítica.

Gambone, M. D. (2005). The Greatest Generation Comes Home. The Veteran in American Society. Texas: A\&M University.

García Hortelano, J. (1992). Tormenta de verano. Barcelona: Seix Barral.

García Serrano, R. (1959). Feria de restos (paisajes, manjares, hombres y vinos de España). Madrid: Editora nacional.

Gilmore, D. D. (1994). Hacerse hombre. Concepciones culturales de la masculinidad. Barcelona: Paidós.

Hagemann, K. y Schüler-Springorum, S. (2002). Home/Front. The Military, War and Gender in Twentieth-century Germany. Oxford: Berg.

Hämmerle, Ch., Überegger, O. y Bader Zaar, B. (2014). Gender and the First World War. NuevaYork:PalgraveMacmillan.Disponibleen:https://doi.org/10.1057/9781137302205.

Haupold Gay, A. (1941). Camarada. Poemas de la hora difícil. Madrid: s. e.

Joran, Th. (1905). Le mesonge du féminisme. Opinions de Léon H... París: Henri Jouve editeur. King, D. (2015). Family Men: Fatherhood and Masculinity in Britain, 1914-1960. Oxford: Oxford University Press. Disponible en: https://doi.org/10.1093/acprof:oso/9780199674909.001.0001.

Lamera, E. (1961). Pequeño y grande nido. El problema de la familia. Bilbao: Ediciones Paulinas.

Last, J. M. (2007). A Dictionary of Public Health. Oxford: Oxford University Press.

Leira Castiñeira, F. J. (2013). La consolidación social del franquismo. La influencia de la guerra en los «soldados de Franco». Santiago de Compostela: Universidade de Santiago de Compostela.

Lowenthal, D. (1985). The Past is a Foreign Country. Cambridge: Cambridge University Press. Disponible en: https://doi.org/10.2307/20042674.

Lüdtke, A. (2011). Male Bodies: Well-Trained Muscles or Beer Bellies? From the 'Master Race' in Nazism to the Ruling Class in East Germany. En J.-H. Lim y K. Petrone (eds.). Gender Politics and Mass Dictatorship: Global Perspectives (pp. 142-168). Nueva York: Palgrave Macmillan.

McVeigh, S. y Cooper, N. (2013). Men After War. Nueva York: Routledge.

Meyer, J. (2009). Men of War. Masculinity and the First World War in Britain. Basingstoke: Palgrave Macmillan. Disponible en: https://doi.org/10.1007/978-0-230-30542-7.

Molinero, C. (1998). Mujer, fascismo, franquismo. La clausura forzada en un «mundo pequeño». Historia Social, 30, 97-117.

Mosse, G. L. (2000) [1996]. La imagen del hombre. La creación de la moderna masculinidad. Madrid: Talasa.

— (2016) [1990]. Soldados caídos. La transformación de la memoria de las guerras mundiales. Zaragoza: Prensas de la Universidad de Zaragoza.

Nash, M. (2014). Feminidades y masculinidades. Arquetipos y prácticas de género. Madrid: Alianza.

Nietzsche, F. (1901). Also sprach Zarathustra: ein Buch für Alle und Keinen. Leipzig: Naumann. 
Niño, A. (2012). La americanización de España. Madrid: Catarata.

Núñez Seixas, X. M. (2005). Los vencedores vencidos: la peculiar memoria de la División Azul, 1945-2005. Pasado y Memoria, 4, 86-116. Disponible en: https://doi. org/10.14198/pasado2005.4.06.

- (2016). Camarada invierno. Experiencia y memoria de la División Azul (1941-1945). Barcelona: Crítica.

Ortega López, T. M. a (2008). Conservadurismo, catolicismo y antifeminismo: la mujer en los discursos del autoritarismo y el fascismo (1914-1936). Ayer, 71, 53-83.

Padovani, I. (1946). Cortesía y distinción (etiqueta y trato social). Barcelona: s/e.

Patterson, J. T. (1996). Grand Expectations. The United States, 1945-1974. New York: Oxford University Press.

Pavlovic, T. (2003). Despotic Bodies and Transgressive Bodies. Spanish Culture from Francisco Franco to Jesús Franco. Albany: State University of New York Press.

Pérez-Gómez, M. A. (2010). Tómbola como paradigma del cine con niño español. Frame. Revista de cine de la Biblioteca de la Facultad de Comunicación, 6, 146-158.

Pueyo Longás, A. (1955). El hogar. Estudios sobre el matrimonio. Barcelona: Editorial pontificia.

Puig, N. (2003). La ayuda económica norteamericana y los empresarios españoles. Cuadernos de Historia Contemporánea, 25, 109-129.

— y Álvaro, A. (2002). Estados Unidos y la modernización de los empresarios españoles, 1950-1975: un estudio preliminar. Historia del Presente, 1, 8-29.

Quiroga, A. (2014). Goles y banderas. Fútbol e identidades nacionales en España. Madrid: Marcial Pons.

Redondet y López-Doriga, L. (1960). Familia en crisis y hogar frío. Madrid: s. e.

Rincón, A. (2014). Representaciones de género en el cine español (1939-1982): figuras y fisuras. Madrid: CEPC/USC.

Roper, M. (2007). Between the Psyche and the Social: Masculinity, Subjectivity and the First World War Veteran. Journal of Men's Studies, 15 (3), 251-270. Disponible en: https://doi.org/10.3149/jms.1503.251.

Rutherdale, R. (1999). Fatherhood, Masculinity, and the Good Life during Canada's Baby Boom, 1945-1965. Journal of Family History, 24 (3), 351-373. Disponible en: https:// doi.org/10.1177/036319909902400307.

Sevillano Calero, F. (2010). Franco. "Caudillo» por la gracia de Dios. Madrid: Alianza.

Shirani, F. (2013). The Spectre of the Wheezy Dad: Masculinity, Fatherhood and Ageing. Sociology, 47 (6), 1104-1119. Disponible en: https://doi.org/10.1177/0038038512469063.

Simón Sanjurjo, J. A. (2012). Fútbol y cine en el franquismo: la utilización política del héroe deportivo en la España de Franco. Historia y Comunicación Social, 17, 69-84.

Tarancón, V. E. (1958). La familia hoy. Madrid: s. e.

Thébaud, F. (1993). La Primera Guerra Mundial: ¿la era de la mujer o el triunfo de la diferencia sexual? En G. Duby y M. Perrot (dirs.). Historia de las mujeres en Occidente, vol. 5, El siglo XX (pp. 31-90). Madrid: Taurus.

Tinker, Ch. (2014). Mixed Masculinities in 1960s British and French Youth Magazines. Journal of Popular Culture, 7 (1), 84-108. Disponible en: https://doi.org/10.1111/ jpcu.12109. 
Uría, Jorge (2014). Iconos de masculinidad. Los años veinte y los ases del fútbol español. En M. Nash (ed.). Feminidades y masculinidades. Arquetipos y prácticas de género (pp. 159187). Madrid: Alianza.

Van Ells, M. D. (2001). To Hear Only Thunder Again. America's World War II Veterans Come Home. Lanham: Lexington Books.

Vigón, J. (1953). Hay un estilo militar de vida. Madrid: Editora nacional.

Vincent, M. (2006). La reafirmación de la masculinidad en la cruzada franquista. Cuadernos de Historia Contemporánea, 28, 135-151.

Viuda Serrano, A. (2013). Santiago Bernabéu y el Real Madrid. Un análisis histórico del mito del fútbol. Política y deporte en la España franquista. AGON International Journal of Sports Sciences, 3 (1), 33-47.

Winchester, I. (2015). So[u]ldiers for Christ and Men for Spain: The Apostolado Castrense's Role in the Creation and Dissemination of Francoist Martial Masculinity. Revista Universitaria de Historia Militar, 4 (8), 143-163.

Wright, S. (2016). Los mutilados de Franco: el Benemérito Cuerpo y la política social en la España franquista. Revista Universitaria de Historia Militar, 5 (9), 75-92.

Zenobi, L. (2011). La construcción del mito de Franco. De jefe de la Legión a Caudillo de España. Madrid: Cátedra.

Zulaika, J. (1989). Chivos y soldados. La mili como ritual de iniciación. San Sebastián: Baroja. 